\title{
OPTIMALISASI PEDIDIDKAN DAN PELATIHAN BABINSA SEBAGAI MOTIVATOR DALAM MENINGKATKAN KETAHANAN PANGAN DI KOTA BANDUNG
}

\section{Edi Marwanto}

IKIP SILIWANGI

edi_mar81@yahoo.com

\begin{abstract}
ABSTRAK
Dalam konteks kehidupan manusia sangat dibutuhkan sumber pangan. Namun, dewasa ini kelangkaan kerap muncul di berbagai tempat di Indonesia. Untuk itu Pemerintah Daerah sesuai dengan amanat desentralisasi harus mampu membuat program untuk pemberdayaan petani guna mewujudkan ketahanan pangan, tak terkecuali Babinsa Kecamatan Kiaracondong Kota Bandung. Penelitian ini menggunakan metode penelitian kualitatif di Kota Bandung, pendekatan deskriptif yang dilakukan melalui observasi, wawancara dan dokumentasi. Model analisis data yang digunakan adalah model analisis data deskriptif kualitatif dengan pendekatan observasi, wawancara, dokumentasi dan studi literature. Hasil penelitian ini yaitu tentang optimalisasi pendidikan dan pelatihan Babinsa sebagai motivator dalam meningkatkan ketahanan pangan di Kota Bandung dapat dikatakan sudah lebih baik dalam mewujudkan ketahanan pangan. Dimana produksi yang dihasilkan menjadi lebih baik dan meningkat, ini dikarenakan pengetahauan dan keterampilan Babinsa dalam membantu petani bercocok tanam juga meningkat. Faktor pendukung utama keberhasilan peningkatan ketahanan pangan di Kota Bandung adalah berjalannya program dengan adanya dukungan dari Pemerintah Daerah serta adanya bantuan dari Babinsa. Hambatannya datang dari masalah rendahnya kualitas sumber daya manusia serta keterbatasan alat pertanian. Hal ini diperlukan adanya sinergi diantara petani, masyarakat serta pemerintah untuk secara bersama-sama mendukung program pemberdayaan petani untuk meningkatkan ketahanan pangan.
\end{abstract}

Kata kunci: Babinsa, ketahanan pangan. Motivator, Pelatihan

\section{A. PENDAHULUAN}

Perubahan penggunaan lahan di Indonesia telah diketahui banyak terjadi. Perubahan terbesar terjadi pada wilayah hutan yang umumnya dikonversi menjadi tanaman perkebunan seperti kelapa sawit, karet, atau komoditas lainnya. Konversi lahan pertanian yang patut diwaspadai adalah bila terjadi pada lahan sawah. Proses pencetakan sawah merupakan proses yang banyak menelan biaya, utamanya dalam membangun infrastruktur dasar seperti irigasi dan bendungan. Pantura Jawa Barat merupakan salah satu wilayah dengan tingkat konversi yang tinggi di Indonesia (Firman 2010). Firman (2010) mengindikasikan bahwa dinamika perubahan lahan banyak dipengaruhi oleh kebijakan BPN dalam perijinan pengusahaan lahan. Dengan demikian data penurunan luasan lahan sawah merupakan salah satu data penting dalam perencanaan bidang pertanian. Konversi aktual lahan sawah perlu ditelaah dalam kerangka Undang-undang No. 41/2009 yang merujuk pada perlindungan lahan pangan 
berkelanjutan. Hal ini ditujukan untuk memberi gambaran awal kondisi konversi aktual (benchmark) dalam kontrol Undang-undang tersebut. Penelitian ini ditujukan untuk mengkaji penurunan luasan sawah dalam wilayah proteksi Undang-undang tersebut dalam kerangka analisis spasial.

Kesulitan yang paling krusial di lapangan selama ini dalam meningkatkan swasembada pangan nasional meliputi, tenaga kerja pertanian di dominasi oleh tenaga kerja tua sedangkan tenaga kerja muda dan berpendidikan semakin enggan bekerja di sektor pertanian karena para tenaga muda lebih memilih pekerjaan lain di luar pertanian, rendahnya transfer teknologi sehingga sulit dan lamban untuk meningkatkan produktifitas karena sumber daya yang rendah, perbatasan modal kerja dan kesulitan mengakses dan perbankan karena tidak terpenuhi persyaratan agunan karena kurang lengkapnya syarat yang dimilki, disisi lain yang harus di waspadai adanya permainan para tengkulak dalam bidang pertanian yang mencakup bahan pertanian dan hasil pertanian serta permodalan yang mencekik petani.

Upaya yang telah dilakukan oleh TNI AD selama ini dalam meningkatkan swasembada ketahanan pangan nasional meliputi: melaksanakan sosialisasi dan temu tani kepada kelompok masyarakat tani binaan di wilayah di bidang pertanian, perkebunan, dan perikanan, melaksanakan pendampingan kepada kelompok petani binaan di wilayah masing masing dalam bidang pertanian perkebunan perikanan, melaksanakan koordinasi dengan bupati atau walikota untuk penyediaan lahan cetak atau ladang baru seluas minimal $10 \mathrm{Ha} /$ lebih dengan mendorong terbitnya surat SID (survei investigation desaign) yang dikeluarkan oleh bupati atau walikota untuk sawah atau ladang sebagai pilot project kodim, melaksanakan cetak sawah atau ladang baru sebagai pilot project kodim kabupaten/kota untuk tanaman pangan ( padi, kedelai, jagung) sesuaikan dengan kearifan lokal dengan lahan seluas $1 \mathrm{Ha}$ atau lebih dalam semester 1 di hamparan lahan seluas $10 \mathrm{Ha}$ atau lebih, yang dilanjutkan dengan penanaman secara berlanjut dan terus menerus sehingga bertambahnya lahan ketahan pangan di masing masing wilayah, melaksanakan kegiatan model kawsan rumah pangan lestari yang di singkat (KRPL) di wilayah bagi kodim kota besar yang memiliki lahan terbatas syarat berlanjut dan terus menerus.

Dengan menyikapi hal tersebut mendorong pemerintah pusat yang terkait untuk merubah paradigma pembangunan pertanian nasional, karena di pandang selain penguasaan wilayah serta pemantauan untuk kelancaran ketahanan pangan ini perlunya melibatakan aparat teritorial yang di ambil dari TNI AD, dengan pelaksanaan di lapangan babinsa yang telah di bekali ilmu pertanian, guna untuk membantu meningkatkan swasembada pangan nasional. Tugas TNI adalah melindungi rakyat, tetapi TNI AD yang mempunyai tugas pertahanan wilayah di darat tidak bisa melihat keadaan bangsa yang mempunyai masalah yang tak kunjung terselesaikan, sisi lain permasalahan tersebut sangat bersinggungan dengan tugas pokok TNI AD di lapangan terutama tugas teritorial, sehingga sesuai intruksi Bapak Presiden sebagai Panglima tertinggi Tentara Nasional Indonesia nomor 5 tahun 2011 tentang " ketahanan pangan dalam menghadapi cuaca ekstrim " yang melibatkan TNI ikut serta dalam keanggotaan sesuai instruksi tersebut, yang diimplementasikan dalam sprin direktif pembinaan ketahanan pangan nomor Sprin/195/I/2015 tanggal 29 januari 2015 tentang program pembinaan ketahanan pangan, disini kewenangan TNI AD dalam peningkatan ketahanan pangan ini adalah membantu para petani, untuk memfasilitasi serta 
mengkoordinasikan dengan pemerintah pusat maupun daerah serta instansi yang terkait dan BUMN yang berhubungan dengan pertanian, yang diimplementasikan dengan turunnya Babinsa di lapangan

\section{B. TINJAUAN PUSTAKA}

Pelatihan merupakan bagian yang menyangkut proses belajar untuk memperoleh dan meningkatkan keterampilan diluar sistem pendidikan yang berlaku dalam waktu relatif singkat dengan metode yang lebih mengutamakan pada praktek daripada teori. Pendidikan dan pelatihan merupakan penciptaan suatu lingkungan dimana para pegawai dapat memperoleh atau mempelajari sikap, kemampuan, keahlian, pengetahuan dan perilaku yang spesifik yang berkaitan dengan pekerjaan (Yuniarsih \& Suwatno, 2011).

Ketahanan Swasembada pangan dapat diartikan sebagai kemampuan untuk memenuhi segala kebutuhan pangan serta kemampuan untuk mampu menyediakan segala kebutuhan sendiri, meliputi bahan-bahan makanan yang didalamnya terdapat hasil pertanian, perkebunan dan lain-lain, dari pihak luar tentang ketahanan pangan tersebut, yang tercermin dari tersedianya pangan yang cukup, baik jumlah maupun mutunya aman merata dan terjangkau. Babinsa adalah Badan Pembinaan Desa yang dulunya diberi nama Bintara Pembina Desa karena kurangnya anggota Bintara di lapangan pada saat itu Banyak Tamtama yang dianggap mampu dan matang dilapangan dari segi kedewasaan berfikir dan bersikap persuasif, karena usianya yang sudah dianggap dewasa serta banyaknya penugasan akibat konflik dibeberapa daerah sesuai perintah lisan Bapak KASAD saat pengarahan di Monas Jakarta dengan mengganti kata Bintara menjadi Badan yang dijabat oleh seorang Bintara atau Tamtama Angkatan Darat yang berpangkat Kopral Dua sampai degan Pembantu Letnan Satu merupakan pelak, selain itu juga melaksanakan pengumpulan data geografi, demografi, kondisi social dan potensi Nasional yang meliputi SDM, SDA/SDB serta sarana dan prasarana di wilayahnya, dan memberikan informasi, situasi dan kondisi wilayah bagi pasukan yang bertugas di daerahnya, serta melaporkan perkembangan situasi kepada Danramil pada kesempatan pertama dengan melaksanakan temu cepat dan lapor cepat dengan berpedoman kepada Siabidibame.

Seorang Babinsa yang dikenal sebagai motivator masyarakat dalam membangun untuk meningkatkan kesejahteraan di wilayahnya, adalah hal yang biasa yang sudah menjadi tugas pokok para Babinsa, untuk memotivasi masyarakat dalam menjalankan program pemerintah terutama pedesaan-pedesaan dengan mengajak, mendengar kesulitan serta hambatan yang dialami masyarakat Desa, untuk diajak membangun dengan mengikuti program pemerintah pusat maupun daerah, hal ini diperlukan seorang Babinsa yang diharuskan mempunyai sumberdaya dan kearifan masyarakat lokal dipedesaan yang umumnya sangat rendah sumberdayanya, serta kemampuan khusus Babinsa ini perlu adanya inovasi yang lebih luas untuk menjalankan tugas yang terintregasi dengan terencana terarah dan terpadu secara utuh.

Disini adalah untuk mengajak masyarakat terutama dipedesaan yang rata-rata memilik isumberdaya yang rendah perlu adanya dukungan dan kepercayaan untuk menjalankan program pemerintah, yaitu dengan memotivasi masyarakat agar lebih giat dan mau bekerja dan meyakinkan tentang kepastian program pemerintah, disisi lain tugas Babinsa selain perannya sebagai motivator adalah untuk memantau pihak lain yang 
merasa terhambat aktifitasnya dengan adanya program pemerintah tersebut, sehingga perlu mendapatkan pengawasan khusus dari seorang Babinsa agar dalam perannya sebagai motivator di masyarakat yang mampu diakui dan dipercaya guna untuk meningkatkan ketahanan pangan.

\section{METODE PENELITIAN}

Metode yang digunakan dalam penelitian ini adalah metode penelitian kualitatif. Moleong (1996) mendefinisikan bahwa penelitian kualitatif adalah suatu penelitian ilmiah, yang bertujuan untuk me-mahami suatu fenomena dalam konteks sosial secara alamiah dengan mengedepankan proses interaksi komunikasi yang mendalam antara peneliti dengan fenomena yang diteliti. Oleh karena itu dalam pene-litian kualitatif peneliti adalah sebagai sumber in-strument yakni sebagai pengumpul data secara langsung. Metode yang digunakan dalam penelitian kualitatif dapat dilakukan dalam berbagai bentuk yaitu melalui : Observasi/ pengamatan, Wawancara, Study Dokumentasi dan Study Literatur. Instrumen yang digunakan dalam penelitian ini adalah menggunakan instrument penyebaran angket dan wawancara, karena sestem penyebaran angket dapat mempermudah dalam pengolahan data penelitian.

\section{HASIL DAN PEMBAHASAN}

Dalam penelitian ini, yang dijadikan indikator untuk mengetahui bagaimana Optimalisasi Pedididkan dan pelatihan Babinsa Sebagai Motivator dalam Meningkatkan Ketahanan Pangan di Kota Bandung. Indikator yang digunakan diantaranya adalah pengetahuan, keterampilan dan konsep diri/ sikap yang dijadikan sebagai tolak ukur dalam mengetahui kompetensi Babinsa. Dalam mendalami data sekunder yang sudah ada, dilanjutkan dengan wawancara yang dilakukan terhadap beberapa informan yang diambil menggunakan teknik pengambilan sampel berupa probability sampling. Adapun analisa yang dilakukan adalah sebagai berikut: Peningkatan Kompetensi Babinsa.

Berdasarkan hasil penelitian tentang Optimalisasi Pedididkan dan pelatihan Babinsa Sebagai Motivator dalam Meningkatkan Ketahanan Pangan di Kota Bandung, diperoleh hasil sebagai berikut : Pengetahuan dari hasil penelitian tentang Optimalisasi Pedididkan dan pelatihan Babinsa Sebagai Motivator dalam Meningkatkan Ketahanan Pangan dengan mengadakan kegiatan baik berbentuk program maupun diluar program yang merupakan inisiatif satuan. Adapun kegiatan tersebut adalah membantu para petani dalam peningkatan pangan. selalu berusaha meningkatkan kompetensi Babinsa dalam bidang keterampilan. dan sikap Dalam upaya peningkatan sikap yang telah dilakukan Kodim adalah dengan memberikan jam komandan baik oleh Danramil maupun oleh Dandim, santi aji diberikan pada setiap kegiatan apel berupa pengucapan Sapta Marga, Sumpah Prajurit dan 8 Wajib TNI, santi karma dalam bentuk penjelasan tentang pentingnya santi aji tersebut dan pembinaan mental secara periodik dilakukan di Kodim baik dari segi rohani maupun mental kejuangan. Oleh karean itu dengan adanya Babinsa membatu dilapangan sedikit meringankan petani dalam meningkatkan ketahanan pangan.

Keterlibatan babinsa dalam peningkatan pangan yang ada di kota Bandung merupakan salah satu cara dalam rangka mempertahankan ketahanan pangan sekaligus menjadi sarana sosialisasi masyarakat terhadap program yang tengah digalakkan oleh pemerintah. Namun demikian, tetap proses pelibatan tersebut perlu didukung dengan 
sistem pendidikan masyarakat yang memadai, sehingga dapat dengan segera membangun kapasitas masyarakat dengan kekuatan ekologi sekitarnya. Hal ini merupakan sumberdaya utama dalam mempersiapkan modal sosial (social capital) dalam peningkatan kualitas kehidupan masyarakat sekitar (Ardiwinata \& Mulyono, 2018).

\section{E. KESIMPULAN}

Optimalisasi Pedididkan dan pelatihan Babinsa Sebagai Motivator dalam Meningkatkan Ketahanan Pangan adalah dengan melakukan beberapa upaya yaitu dalam bidang pengetahuan dengan mengadakan pendidikan dan pelatihan bagi Babinsa secara periodik, pembekalan bagi Babinsa yang baru masuk satuan dan melatih Babinsa yang akan melaksanakan seleksi pendidikan secaba. Sedangkan untuk peningkatan keterampilan dapat dilakukan dengan melaksanakan latihan program dari latihan perorangan dasar serta jabatan, mempedomani referensi latihan dalam penyelenggaraan latihan, pemanfaatan program pembinaan kemampuan Babinsa untuk meningkatkan keterampilan dan menerapkan sistem KSA (Kemana, Siapa dan Apa) bagi Babinsa setiap harinya sehingga mempunyai target dalam bekerja. Untuk meningkatkan sikap dapat dilakukan dengan pemberian jam komandan secara periodik, pembinaan mental baik rohani (agama) maupun tradisi kejuangan, pemberian motivasi oleh motivator dan pemberian reward and punnishment bagi Babinsa yang berprestasi atau yang melakukan pelanggaran

\section{F. DAFTAR PUSTAKA}

Ardiwinata, J. S., \& Mulyono, D. (2018). COMMUNITY EDUCATION IN THE DEVELOPMENT OF THE COMMUNITY. Empowerment, Vol. 7 (1), 25-35.

Firman. (2010). Kebijakan Perijinan Lahan. Jakarta: Lubuk Agung.

Moleong, L. J. (1996). Metodologi Penelitian Kualitatif. Bandung: Remaja Rosdakarya.

Yuniarsih, T., \& Suwatno. (2011). Manajemen Sumber Daya Manusia. Bandung: Alfabeta. 